\title{
The Impact of Climate Change on the Annual Variation of Shallow Groundwater Levels in Latvia
}

\author{
Didzis Lauva $^{1}$, Inga Grinfelde ${ }^{2}$, Arturs Veinbergs ${ }^{3}$, Kaspars Abramenko $^{4}$, Valdis Vircavs ${ }^{5}$, Zane Dimanta ${ }^{6}$, Ilva \\ Vitola ${ }^{7},{ }^{1-7}$ Latvia University of Agriculture
}

\begin{abstract}
The long-term annual regime of shallow groundwater levels is analysed in two different time periods according to the dominance of continental and oceanic air masses in Latvia. Observed and modelled long-term mean monthly groundwater levels for the reference period (1961-1990) and a future period (2070-2100) are transformed into relative values and the contours are derived for each month of the year. In both periods, the main difference between the mildly oceanic western coastal part of Latvia and the continental eastern part is the pattern of the winter regime which responds differently to snowmelt. In the coastal areas, where the degree of climatic continentality is low, groundwater levels during the winter are higher than those areas in the inland eastern part of the country. From May to September, there is only temporal difference between the groundwater levels in those two parts of Latvia. There are significant differences of relative groundwater levels between reference and future periods during the winter months.
\end{abstract}

Keywords - METUL, continentality, hydrological year

\section{INTRODUCTION}

Groundwater systems are dynamic and adjust continually to short-term and long-term changes in climate, groundwater withdrawal and land use $[5,8]$. Groundwater level fluctuations are important firstly for environmental protection: maintaining the groundwater equilibrium system, controlling groundwater level fluctuation and protecting against severe land subsidence [14]. Secondly, for agriculture and forestry industries as water is one of the resources on which sustainable yield quality and quantity is dependent [19]. These fluctuations can be described over a long-term period, divided annually and averaged per month creating a specific shaped function, which represents groundwater level fluctuation regime.

The classical Latvian long-term groundwater level fluctuation regime can be described as an M-shaped function which represents two groundwater level maximums and minimums. The first and major maximum occurs in spring (April) when, in addition to the rainfall, the snowmelt enhances surface runoff and groundwater recharge. Accordingly, this maximum is called the spring maximum. In the summer, developed vegetation cover combined with warm temperature, increases evapotranspiration, and the groundwater levels decrease reaching its major minimum in August, called the summer minimum. Starting from September, in the autumn months, groundwater levels tend to increase due to frequent rainfalls and slowly decreased evapotranspiration. The second maximum occurs in the beginning of winter (December) and it is called the autumn maximum. Due to the low temperatures and frozen ground surface during the winter months, the groundwater levels tend to decrease reaching a winter minimum in February and it is called the winter minimum [20].

Latvia is situated within the transitional zone between the oceanic north-western part of Europe and the continental north-eastern part of Europe; between the oceanic or maritime part and the interior regions of Europe. It has a vast area of flat plain-land without any natural barriers to air mass movement. This results in high daily variability, diversity and inter-annual changes in air mass frequency. The annual course of recurring air mass combinations, as well as the cycle of net radiation, near-surface temperature, amount of precipitation, elements of water balance and phonological phenomena, all have explicit seasonality. Mapping of the degree of the climatic continentality describing it with the Conrad coefficient has been done [3]. Continentality is inversely proportional to oceanity and both terms describe the climate of areas influenced by air masses over large continental or oceanic bodies. Such assumption suggests that in Latvia the monthly groundwater level varies depending not only on climate conditions but also on continentality. The objective of this paper is to analyze the spatiotemporal patterns of the longterm mean monthly groundwater levels in Latvia in two different time periods according to the spatially changing degree of the climatic continentality and to highlight the significance of climate change impact on groundwater level regime.

The impact of climate change has been widely studied in different hydrological research directions, such as water resources management and sustainability [10] and flood risk management [9]. In this study the groundwater level fluctuation regime is compared between two different time periods thus allowing analysis of the impact of climate change. The periods are identified as reference period (1961-1990) and future period (2070-2100). In the reference period actual observations were summarized, but for the future period the groundwater model METUL was used. There are several groundwater models, which calculate daily groundwater levels from meteorological data [1], but model METUL was chosen as known and most appropriate model [13].

\section{MATERIALS AND METHODS}

\section{Data collection and verification}

Water-level measurements from observation wells are the principal source of data. Long-term, systematic measurements of water levels provide essential data needed to evaluate changes in the resource over time, to develop groundwater models and forecast trends, and to design, implement, and 


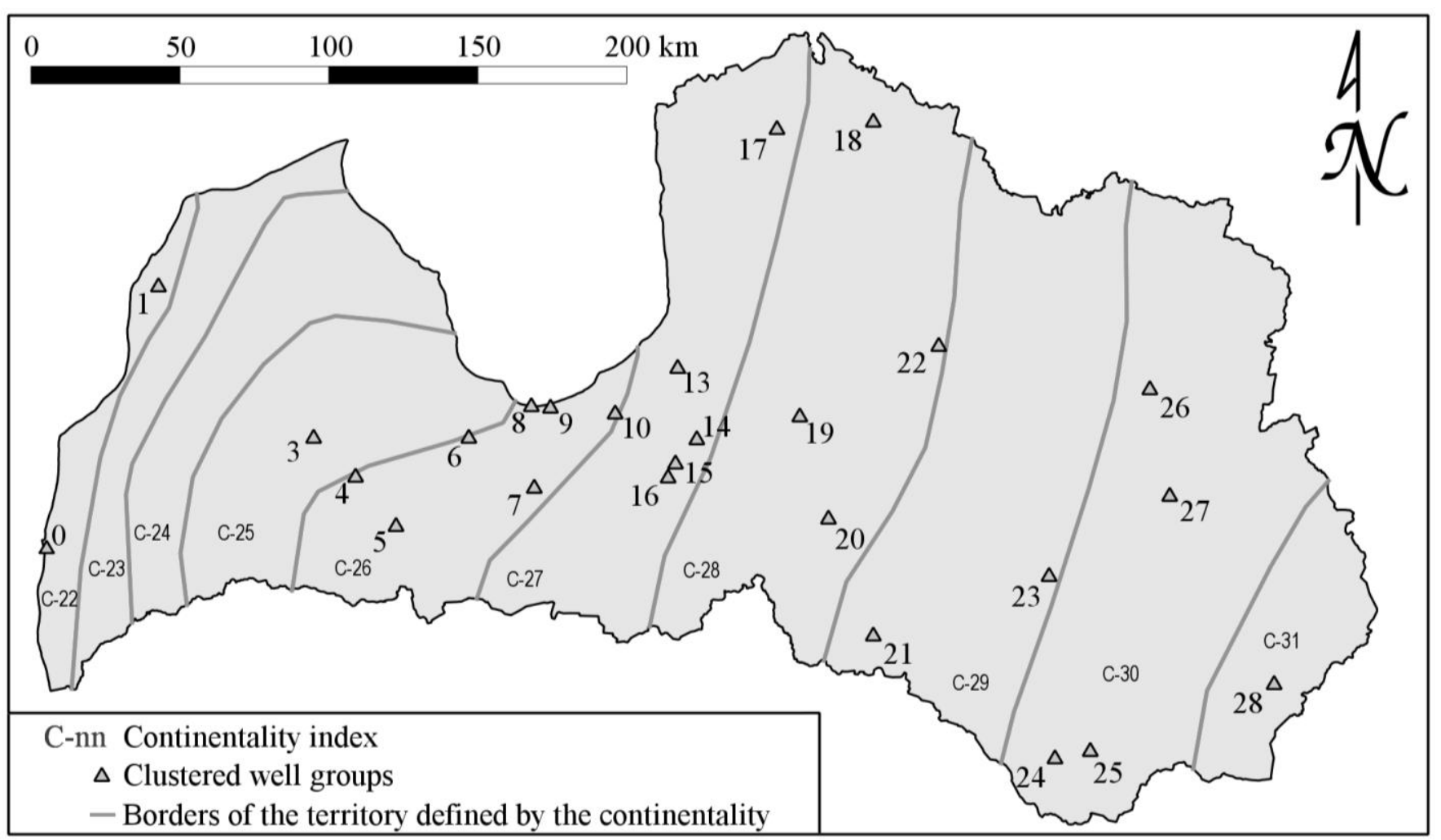

Fig. 1. Map of the clustered well group geographically weighted centres and continentality index

monitor the effectiveness of groundwater management and protection programs [11]. Shallow groundwater levels in Latvia have been actively monitored since the 1960s [15]. In this study the data was obtained from the well and groundwater level database of the Latvian Environment, Geology and Meteorology Centre that met the following conditions: first, groundwater level time series period data is from 1961 till 1990, second, depth of well filter is less than 10 meters from the ground surface and the filter is penetrating highly conductive sand, third, the data collection frequency for selected well is less than seven days, fourth, wells with a maximum 3 meters deep water table from the ground surface.

Graphoanalytical and statistical screening of data were used to exclude improbable data values, such as input mistakes, incorrect measurement units and wrong well identification numbers.

Altogether data from 182 wells was used in this study. All wells were clustered in 29 different groups, but 3 groups were discarded due to the data inconsistency. In each group there was at least one well with observed groundwater level time series data, which represents the reference period. In the groups with more than one well, the observed groundwater level time series were transformed into normalized values and compared between each other and wells with worst data series and poor reciprocal correlation, were identified and discarded. Remaining observations were averaged over the group where they belonged. Clustered well group locations and continentality index are represented in Fig.1.

\section{Mathematical transformations}

Interpolation was used to fill the daily values where observations had not been made. In this research studying correlations between groundwater level fluctuations and continentality, it is crucial to minimize the influence of nonclimatic parameters such as groundwater depth and the hydraulic properties of aquifer medium. The standardization was done to remove impact of local conditions such as different amplitude and absolute mean groundwater level, ground surface, slope, soil grading composition, land use and other.

After following mathematical transformations, the final data consists of three datasets. The first dataset represents observations in the reference period, the second - modelled groundwater levels in the reference period and the third modelled groundwater levels in the future period. All datasets contain 12 standardized long-term monthly mean values for each clustered well group, altogether 312 values per dataset.

\section{Interpolation}

There is a large variability in the groundwater level monitoring frequency. Mostly groundwater level measurements were made every three days, but in the raw observed time series there are periods when the frequency was only once per week. If the monitoring frequency exceeded 7 days, such periods were extracted and discarded. Otherwise, in order to get daily groundwater levels in each selected well the interpolation (see equation (1)) of monitoring data was used. 


$$
l_{i}=l_{\text {prev }}-\frac{l_{\text {prev }}-l_{\text {next }}}{n} i
$$

In the equation 1 :

$n$ - is days between the previous and next observed groundwater levels,

$l_{\text {prev }}$ - is the previous or the first measured groundwater level,

$l_{\text {next }}$ - is the next or the last measured groundwater level

$l_{i}$ - is the groundwater level in the $i_{\text {th }}$ day,

$i$ - is the day in a row.

\section{Standardization}

The groundwater levels in the database were measured as the depth from the ground surface to the water table; the larger value represents deeper groundwater.

In order to standardize groundwater data from different wells, time series containing mean monthly groundwater levels were normalized twice. Firstly, the groundwater observation series were inversely normalized for each hydrological year (12 month period starting from October) thus giving values between 0 and 1 using equation 2

$$
l_{i}^{n}=1-\frac{l_{i}-l_{\min }}{l_{\max }-l_{\min }}
$$

where

$l_{i}^{n}$ - is the inverse normalized relative position of the groundwater table for the $\mathrm{i}_{\mathrm{th}}$ month.;

$l_{i}$ - is the absolute mean monthly groundwater level in the $\mathrm{i}_{\text {th }}$ month;

$l_{\min }$ - is the maximum mean monthly groundwater level;

$l_{\max }$ - is the minimum mean monthly groundwater level.

After such normalization approach value 0 represents deeper groundwater level and value 1 represents higher groundwater level for each hydrological year. This transformation gives more logical perception of groundwater levels - when groundwater has reached its minimum, the value is 0 , and when it reaches its maximum, the value is 1 . Otherwise, after normalization the results can be easily misinterpreted, and, transforming absolute to normalized groundwater levels, the latter was inversed subtracting calculated value from maximal possible value 1 . In this study it is called first-time, inverse normalization. Using the normalized data of each hydrological year, the long-term normalized mean groundwater levels were averaged for each month.

The second normalization was made for the first time normalized long-term monthly mean groundwater level. The second-time normalization is a simple amplitude normalization calculation. The described normalization method was adapted and modified from [2].

$$
l_{i}^{N}=\frac{l_{i}^{n}-l_{\min }^{n}}{l_{\max }^{n}-l_{\min }^{n}}
$$

In the equation 3 :

$l_{i}^{N}$ - is the double normalized relative position of the groundwater table for the $i$ 'th month

$l_{i}^{n}$ - is the relative mean monthly groundwater level in the i th month

$l_{\max }^{n}$ - is the maximum mean monthly groundwater level

$l_{\min }^{n}$ - is the minimum mean monthly groundwater level

\section{Modelling}

The groundwater model METUL is a mathematical conceptual hydrological model which estimates daily groundwater level. Input data include daily mean air temperature, total amount of precipitation and vapour pressure deficit. During the study, the modification of the model has been done adding the user interface and possibility to automatically calibrate the parameters using Simplex algorithm [16]. Previously the calibration has been done manually and input and calculated data management was very uncomfortable.

Model parameters for each chosen well were estimated by calibrating and validating the model on the observed groundwater levels in the reference period. Obtained parameters describe hydrophysical properties of the chosen well. Assuming that these parameters do not change greatly over time, it is possible to compare model results, which are calculated in different time periods. In this study the model parameters obtained in the reference period were used to calculate the groundwater levels with the model in the future period. After the groundwater time series were calculated, the standardization was made for each well.

The climate model which describes the future period was freely chosen from previous research. It was neither best nor worst climate model, but one of the possible calculated models [18]. The climate model was used for both time periods thus allowing to compare the climate model applicability.

\section{Mapping}

Finally, the mapping has been done over all of Latvia using the geographical information system (GIS) Grass GIS. It is an open source software and previously it has been widely used in a broad range of different geographical studies, such as groundwater flow calculation [7], land-use impacts on watershed response [4], drain network analysis [12], etc.

Relative long-term monthly mean values were interpolated using an inverse distance weighting interpolation method and three mapsets for each dataset were created. Each mapset contains 12 raster maps, which represents spatial distribution of standardized long-term mean monthly groundwater levels. The raster statistics were calculated for all individual territories divided by continentality.

\section{RESULTS AND DISCUSSION}

The results represent relative long-term mean monthly groundwater levels for the reference period and future period. The results were analysed by the degree of their continentality 

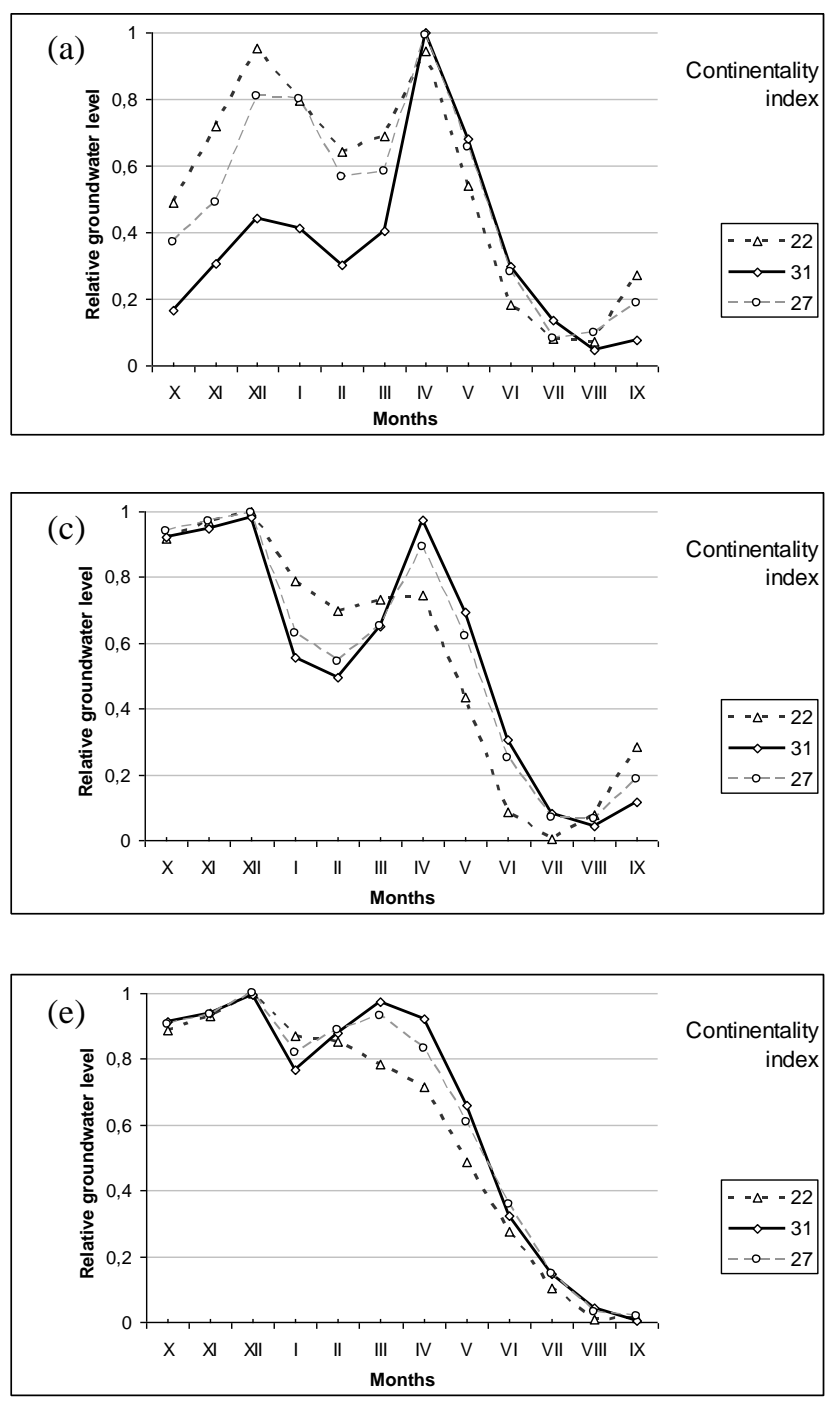
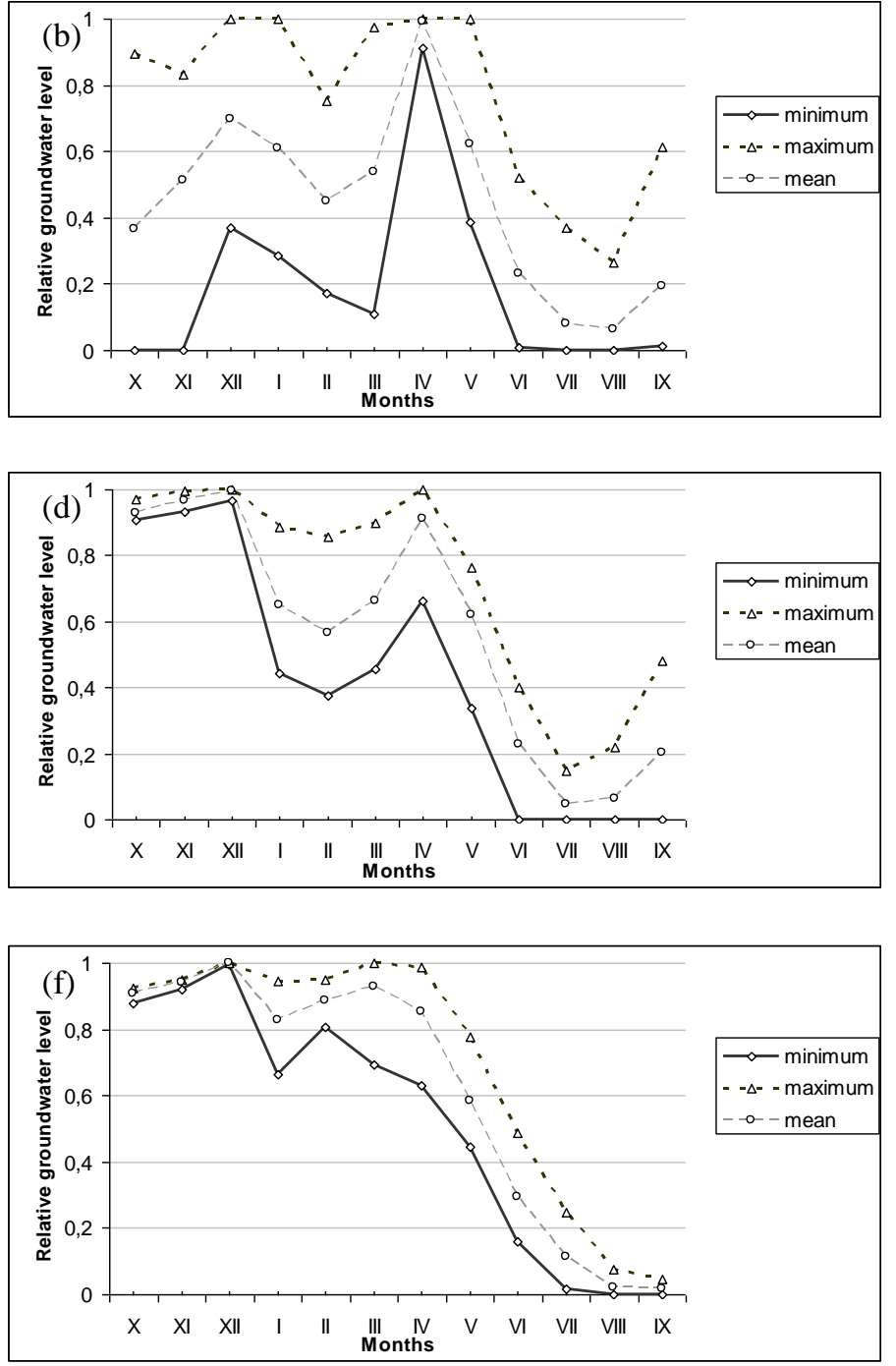

Fig. 2. (a) Observed groundwater levels by continentality index; (b) Observed groundwater levels by maximum and minimum in Latvia; (c) modelled groundwater levels in reference period by continentality index, (d) modelled groundwater levels in reference period by maximum and minimum in Latvia; (e) modelled groundwater levels in future period by continentality index, (f) modelled groundwater levels in future period by maximum and minimum in Latvia

(Fig. 2.a, 2.c, 2.e) representing the mean groundwater level by the index of continentality, over all of Latvia (Fig. 2.b, 2.d, 2.f) representing minimal, maximal and mean groundwater levels, and spatiotemporally (Fig 3).

\section{Reference period}

The results showed that in reference period observed monthly mean, minimal and maximal (Fig. 2.b) and the same modelled relative groundwater observations (Fig. 2.d) correspond to the previously defined groundwater regime [20] in Latvia representing all four crucial groundwater regime extremes - autumn and spring maximums, and winter and summer minimums. The same conclusion can be stated analysing reference period results divided by degree of continentality (Fig. 2.a, 2.c).

The winter minimum is very close in observed and modelled data between the territories with different continentality and all over Latvia (Fig. 2). In both observed and modelled datasets, in the territories with higher continentality the winter minimum is significantly lower than in the territories with lower continentality. In the territories with lower continentality, i.e. western part of Latvia, the winter thaws occur more frequently, thus ensuring groundwater recharge. In the eastern part, where continentality index is higher, winters are harsh and without frequent thaws limiting groundwater recharge.

The spring maximum is reached in the western part of Latvia where degree of continentality is lower (Fig. 2.a, 2.c, 3.a). The last remains in the south-eastern part with higher degree of continentality (Fig. 3.c), despite modelled data showing noticeably lower mean spring maximum (Fig. 2.c). At the same time it can be seen, that during the spring maximum there is significant amplitude between minimal and maximal groundwater levels all over Latvia (Fig 2.d). There may be two possible reasons for such results. Firstly, the groundwater model METUL may have some mathematical properties, which incorrectly calculates spring thaw. Secondly, the derived input data from chosen climate model for modelling may be of low quality on spatial distribution. The 
1961-1990, observed
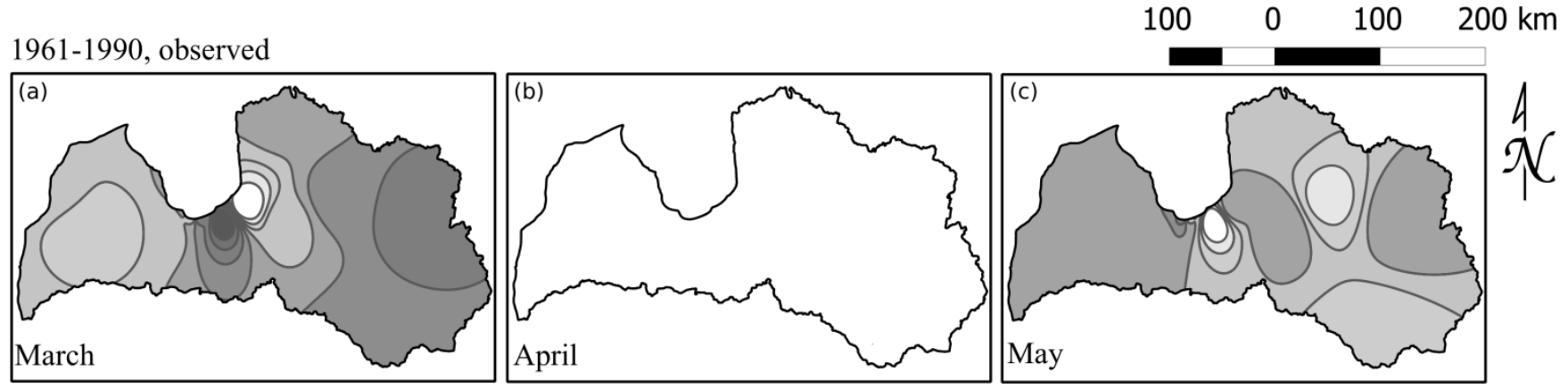

1961-1990, modelled
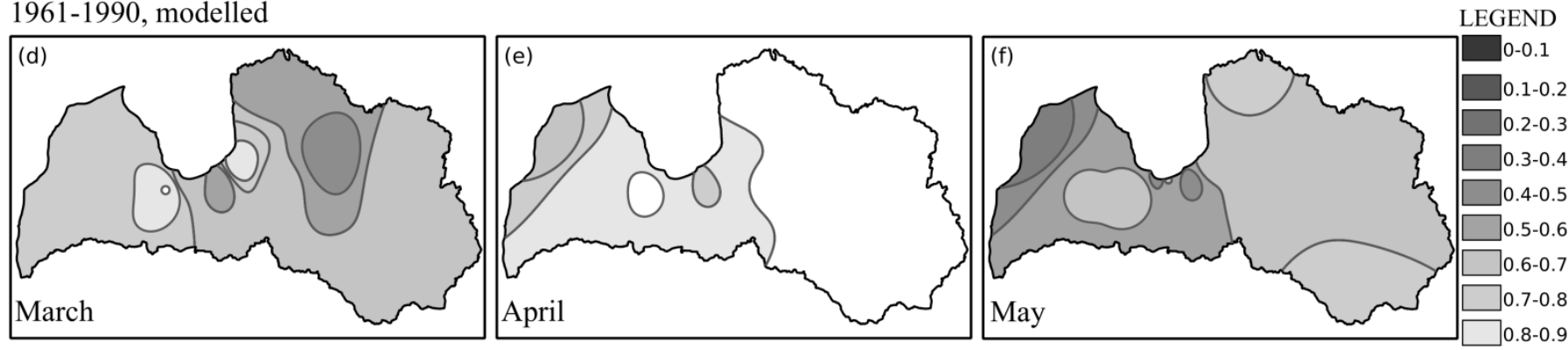

2070-2100, modelled
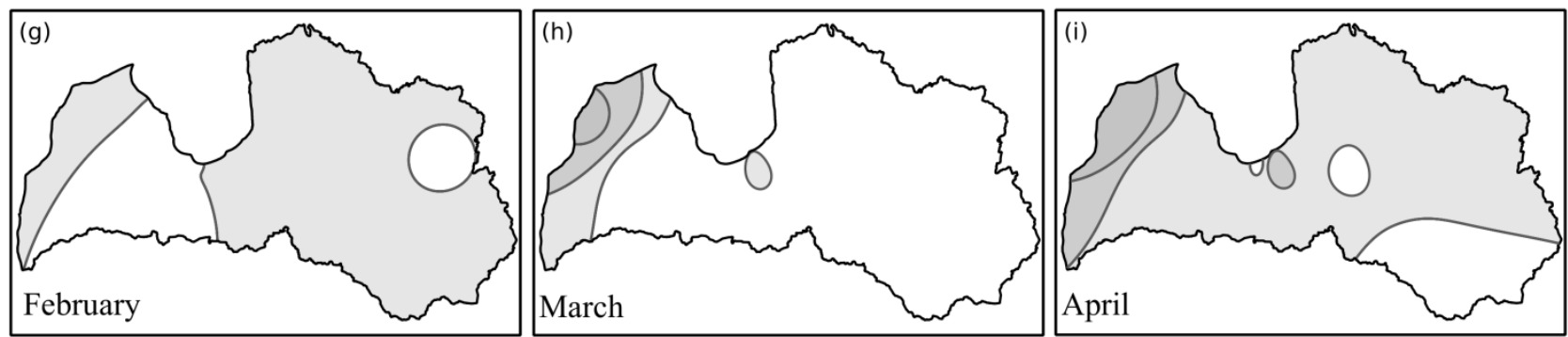

Fig. 3. Observed and modelled relative groundwater levels in the spring period

first assumption can be tested by modelling groundwater levels on the observed meteorological data. Another consideration should be taken into account that the groundwater model METUL works fine in the winter period, when precipitation accumulates as snow and the winters have thaws. Since the METUL has not yet been tested on the observed meteorological data, it is not possible to state whether meteorological data from climate model or model METUL itself gives rise to such uncertainty.

Despite it not being possible to distinguish previously described uncertainty, comparing modelled results within each other, it seems likely that both, model METUL and chosen climate model are not very accurate for the autumn months from October till December. Observed relative groundwater values differ between areas with different continentality and have high standard deviation all over Latvia, but modelled data in these months shows almost no or very low relative groundwater level differences due to continentality (Fig. 2.c, 2.d). During these months multiple factors combine and affect the groundwater recharge. The evapotranspiration decreases accordingly to the lower temperatures and vegetation cover [6]. Model METUL calculates evapotranspiration only from temperature and relative humidity, but not from vegetation cover. In these months the precipitation is prolonged, but not very intense [17]. The described results are the essential difference between observed and modelled data in the reference period.

Analysing the data spatiotemporally it can be seen that from March till May the observed groundwater levels start to increase in the western part of Latvia, Kurzeme, especially in the central part of Kurzeme (Fig.3.a). Therefore it can be correlated with elevation. The modelled groundwater levels show that spring maximums have been reached in the most north western part of Kurzeme in March, but in all other parts of the Latvia the spring maximum occurs in April (Fig 3.d, 3.e). It should be added that in the modelled data the autumn maximum is greater than spring maximum in the territories with index of continentality lower than 25 . The eastern part of Latvia has the best spatial coincidence between observed and modelled data in April, but in May the modelled data is more smoothly spatially distributed than observed data. In observed data, it seems that the elevation affects groundwater levels delaying the decline. In the north-eastern part, near the region's center there is Vidzeme's highland and the groundwater levels in May are slightly higher than the surrounding area. The same effect can be seen in the southeastern part, where Latgale's highland is located.

The spatiotemporal analysis shows an artefact around the capital city, Riga. Most notably it can be seen in observation mapsets (Fig. 3.a, 3.b, 3.c). It can be assumed, that such 
artefact is of anthropogenic origin. The groundwater regime near urbanized territories is affected by groundwater extraction and water supply facilities.

Cross-correlation analysis from April to July demonstrates temporal $~ 14$ days offset between territories with lowest and highest degree of continentally, though in modelled data this offset is slightly larger (Fig. 2.a, 2.c).

In general, the observations and modelled data in the reference period corresponds to classical Latvian long-term groundwater level fluctuation regime creating M-shaped function in each separate territory which is divided by the index of continentality. Model METUL can be used to spatiotemporally evaluate the relative long-term mean monthly groundwater levels.

\section{Future period}

In the future period the winter minimum of groundwater levels will increase (Fig. 2.e, 2.f). In the territories with low degree of continentality, close to the Baltic Sea, the groundwater regime will be different from the reference period. The maximum groundwater level will be reached in December, and then it will slowly decline. The shape of longterm mean monthly groundwater level fluctuation regime will became $\Lambda$-shape with very steep increase in autumn months and gradual decrease from winter maximum in December till summer minimum in August. However in the territories with degree of continentality greater than 24 , the regime will stay the same classical Latvian M-shaped groundwater level regime (Fig. 2.e). Such regime differences cannot be distinguished over all of Latvia, where minimal, maximal and average values represent $\mathrm{M}$-shaped groundwater level regime (Fig. 2.f). Thus, dividing the territory of Latvia by continentality indexes, allows finding additional crucial concealed characteristics of the groundwater level fluctuation regime.

The first crucial difference between reference and future periods is that in the territories where the groundwater level fluctuation regime stays M-shaped, the properties of the future period are similar to the reference period. As continentality index increases, the winter minimum is more pronounced. There is noticeable temporal offset between territories with lowest and highest degree of continentally which is not temporally linear. The higher offset is in February, when the average standardized groundwater level in the territory with the smaller continentality index 22 is equal to the level in the territory with higher continentality index 31 obtained in mid April. The offset is more than 2 months and it gradually declines to $\sim 14$ days obtained in July (Fig 2.e).

The second crucial difference between reference and future periods is 1 month offset of the spring maximum in the territories, where the $\mathrm{M}$-shaped groundwater level fluctuation regime has been determined. In these territories the spring maximum occurs in March (Fig. 3.h.) unlike the reference period, where it occurs in April (Fig. 3.b., 3.e.).

These results can be explained by different temperature regime. It has an impact on snow accumulation in winter. The winter thaws occur more frequently and subsequently the groundwater recharge in the winter period is increased.
The third important difference is prolonged summer minimum in future period and extremely steep increase in September and October. These results can be explained by different precipitation and evapotranspiration regime, as defined by the chosen future climate model.

Analysing the data spatiotemporally it can be seen that in the territories with low continentality index, north-western part of Latvia, long-term mean monthly groundwater levels gradually decrease. This territory has $\Lambda$-shape long-term groundwater level fluctuation regime. In the territories with M-shape regime, groundwater levels tend to change similarly as in the reference period, firstly the spring maximum is reached in the areas with lower continentality index (central part of Latvia) and lastly - in the areas with higher (eastern part of Latvia) (Fig. 3.g., 3.h., 3.i.).

Mathematically it is possible to derive absolute values of groundwater levels from the relative values inversing the standardization formula (equation 2). To achieve this, it is necessary to know the absolute minimum and maximum groundwater levels. However, to find such values, it is necessary to undertake further research. It should be possible to classify the aquifer layers by the lithological materials and for each class allocate possible groundwater fluctuation amplitude. If the amplitude is known, the average groundwater level can be found. Combining amplitude with average groundwater level, the minimum and maximum can be obtained.

There are proven long-term monthly average normalized ground-level spatial and temporal differences, which depend on continentality and spatial climate variability. In this research the obtained results confirm previous studies [2].

\section{CONCLUSIONS}

The main conclusions that can be drawn from the present results are as follows:

In the reference period observed monthly mean, minimal and maximal and both in the same and future period modelled relative groundwater observations over the entire Latvia correspond to the defined M-shaped classical groundwater regime in Latvia [20] representing all four crucial relative long-term mean monthly groundwater regime extremes. Dividing the territory of Latvia by continentality index, it was found that in the future period in the territories with a continentality index lower than 24 , the regime differs from classical groundwater regime creating an $\Lambda$-shaped regime with very steep increase from September to December, and gradual decrease from December to September.

In both periods, observed and modelled data show that there is a temporal offset between territories with different continentality from the spring to the end of the summer. In the territories with classical groundwater level fluctuation regime, the winter minimums tend to be higher and spring maximums are reached earlier in the western part of Latvia where the continentality index is lower. In the future period the spring maximum occurs in March unlike the reference period, when it occurs in April. The summer minimum will be prolonged, 
but increase in September and October will be extremely steep.

The spatiotemporal analysis shows an artefact around the capital city, Riga. Such artefacts should be eliminated in future research.

The study proves the groundwater model METUL applicability to the groundwater level fluctuation studies and the model results are comparable with observations made during the reference period. Future research work on ground level variability has to focus on uncertainty assessment in the METUL model using Monte-Carlo or other methods.

It is possible to continue the research in a number of directions - separately studying other climate models, combining all modelled groundwater level time series into one using uncertainty strategies and subsequently predict possible impact of climate change describing it quantitatively with percentiles, and to obtain the absolute groundwater levels spatiotemporally.

\section{ACKNOWLEDGMENTS}

This work has supported by the ESF within the framework of the project "Establishment of interdisciplinary scientists group and modelling system for groundwater research" $\mathrm{Nr}$. 2009/0212/1DP/1.1.1.2.0/09/APIA/VIAA/060

\section{REFERENCES}

1. Bergström, S. 1995. The HBV model. In: Singh, V.P. (eds.), Computer Models of Watershed Hydrology. Water resources publications, Highlands Ranch, CO., 443-476.

2. Chelmicki, W. 1993. The annual regime of shallow groundwater levels in Poland. Ground Water. 31(3), 383-388.

3. Draveniece, A. 2007. Okeāniskās un kontinentālās gaisa masas Latvijā. Latvijas Veğetācija, 14, 135.

4. Doe, W., W., Saghafian, B., Julien, P. 1996. Land-Use Impact On Watershed Response: The Integration Of Two-Dimensional Hydrological Modelling And Geographical Informaion Systems. Hydrological Processes, 10. 1503-1511.

5. Duchan, D., Drab, A., Khaddour, A., Julinek, T., 2008. Evaluation of risks related to ground water regime changes. In: 3rd International conference on water resources and arid environments and the 1st arab water forum, Book of abstracts. Ryadh, Saudi Arabia, 95.

6. Freeze, R.A. \& Cherry, J.A. 1979. Groundwater. Prentice Hall, Inc. Englewood Cliffs

7. Gebbert, S. 2007. Konzeption eines gekoppelten Stromungs und Stofftransportmodells in GIS GRASS. In:PhD thesis, Institut fur angewandete Geowissenschaften, Techniche Universitat Berlin

8. Genksu, W., Lingyuan, Y., Ling, C., Kubota, J. 2005. Impacts of land use changes on groundwater resources in the Heihe River Basin. Journal of Geography Sciences. 15(4), 405-415

9. Gouldby, B.P., Sayers, P.B. Mulet-Marti, J. Hassan, M.A.A.M., Benwell, D. 2008. A methodology for regional-scale flood risk assessment." Institution of Civil Engineers Water Management

10. Gupta, S.K. 2010. Modern hydrology and sustainable water development. Wiley-Blackwell

11. Houston, J.F.T. 1983. Groundwater systems simulation by time-series techniques. Ground Water. 21(1), 301-310.

12. Jasiewicz, J. 2009. Towards the topologically correct drainage network: integration between TAS GIS and GRASS GIS software. GIS Ostrava.

13. Krams, M. Ziverts, A., 1993. Experiments of conceptual mathematical groundwater dynamics and runoff modelling in Latvia. Nordic Hydrology. 24, 243-262.

14. Kumar, C.P., Singh R.D. 2010. Impact of climate change on groundwater resources. In:Proceedings of 2nd National Ground Water congress. New Delhi, 332-350.

15. Levina, N., Levins, I. Gavena, I. 1998. Latvijas pazemes ūdeṇu resursi. Dzilna, I. (red.), Rīga, Valsts Ģeologiijas Dienests
16. Lauva, D., Abramenko, K., Veinbergs, A., Vircavs, V. 2011. Gruntsūdens līmena un noteces modelēšanas rīku METUL un METQ attīstība. Latvijas Universitātes 69.konference. Ģeologijas sekcijas apakšsekcija "Baltijas artēziskā baseina pazemes ūdeni". Referātu tēzes. Rīga, LU Ģeogrāfijas un Zemes zinātnuu fakultāte, 34.-35.

17. Lizuma, I. 2007. An analysis of a long-term meteorological data series in Riga. Folia Geogr. 7, 53- 61.

18. Sennikovs, J., Bethers, U. 2009. Statistical downscaling method of regional climate model results for hydrological modelling. In:Proceedings of 18th World IMACS / MODSIM Congress.

19. Schleyer, R. 1994. Quantification of groundwater vulnerability usingstatistical methods. In:Proceedings of the Helsinki Conference. 8596.

20. Толстов Я. Б., Левина Н. Н., Прилукова Т. М., и др. 1986 Изучение режима, баланса подземных вод, экзогенных геологических процессов и ведение государственного водного кадастра (подземные воды) в Латвийской ССР на 1984-1986 г. Г.(Сводный отчет за период 1976-1986 г.г.). Рига, Фонды, \#10402.

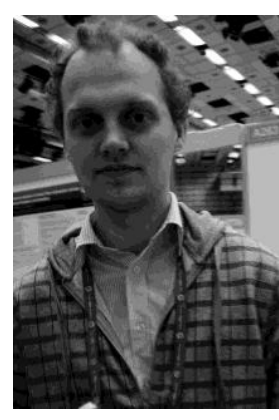

Didzis Lauva, Mg.Sc., Researcher and independent consultant, Faculty of Rural Engineering, Latvia University of Agriculture since 2010. Has two masters degrees; in physics, focusing on vision science (2008, Faculty of Physics and Mathematics, University of Latvia) and in geography (2011, Faculty of Geography and Earth Sciences, University of Latvia).

Previous work experience covers wide subjects where critical analythics, programming, planning, management and decision making were necessary; has worked as assistant in Institute of Solid State Physics, previously as engineer and dispatcher in public transport company "Rigas Satiksme".

Current work assignments includes groundwater regime and time series analysis with focus on programming and modelling, geoinformatics and data analysis. Member of European Geosciences Union (EGU).

Address: 19 Akademijas street, LV-3001, Jelgava, Latvia

Phone: +371 29945987

E-mail: didzis@lauvadidzis.com

Web: www.lauvadidzis.com

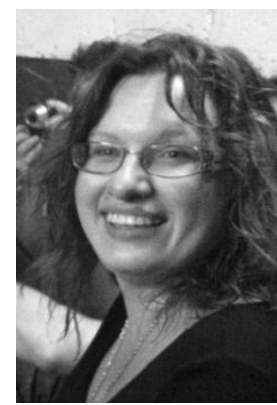

Inga Grinfelde, Mg.sc.env. Assistant profesor in Latvia University of Agriculture, Faculty of Rural Engineering, Department of Environmental Engineering and Water Management, third year $\mathrm{PhD}$ student and scientific researcher at Scientific laboratory of Forest and Water Recourses. Mine research activities related to Hydrological modelling using regional models (METQ); Forest management technologies impact on forest hydrology; Flood risk management of anthropogenic impacts on river hydrology.

Address: 19 Akademijas street, LV-3001, Jelgava, Latvia

E-mail: inga.grinfelde@1lu.lv

Phone: +371 29442763

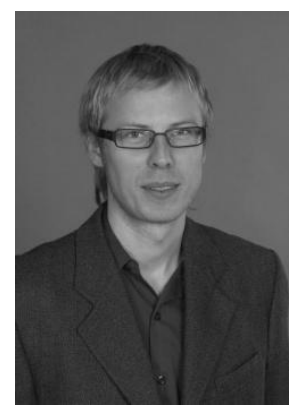

Arturs Veinbergs, B.sc.ing. Master student, Assistant, Department of Environmental Engineering and Water Management, Latvia University of Agriculture (LUA). Bachelor of Science (Environmental Management and Environmental Engineering) LUA, 2010. Master thesis "Influence of Groundwater Fluctuations on Nitrate Nitrogen Runoff in Open Channels". Publications: author/co-author of 8 scientific papers. Research interests: water quality modelling, groundwater monitoring in Latvia. Address: 19 Akademijas street, LV-3001, Jelgava, Latvia

Phone: +371 63029908

E-mail: aarts@inbox.lv 


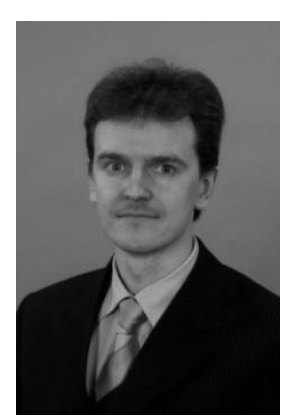

Kaspars Abramenko, Mg.sc.ing, lecturer, Faculty of Rural Engineering, Latvia University of Agriculture. Since 2000 he is among the academic staff in the department of Environmental Engineering and Water Management. In 2002 he graduated MSc studies on Environmental Engineering Science.

Experience of 13 years research in agricultural impact assessment on water bodies and water quality modeling is connected to his $\mathrm{PhD}$ thesis "Agricultural diffuse source pollution in Latvia”. He mainly deals with multi scale agricultural runoff monitoring data collection in Latvia to estimate pollution source apportionment within rive basins.

As a scientist he is involved in national water monitoring programmes and international research projects BEAROP, BSRP, COST, RECOCA concerning nutrient losses from agricultural land. Since 2010 he participates in the ESF project „Establishment of interdisciplinary scientist group and modeling system for groundwater research".

Address: 19 Akademijas street, LV-3001, Jelgava, Latvia

Phone: +37163029908

Email: kaspars.abramenko@llu.lv

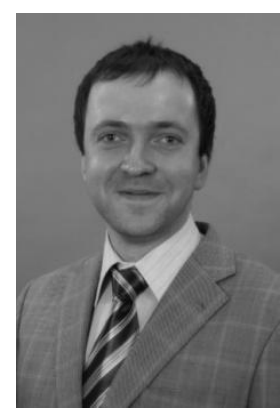

Valdis Vircavs, Mg.sc.geol. is a lecturer in Latvia University of Agriculture, Faculty of Rural Engineering, Department of Environmental Engineering and Water Management, second year $\mathrm{PhD}$ student and scientific researcher in ESF project.

$\mathrm{He}$ was involved in international and national projects: EU Co-financed BONUS program RECOCA, National research program 7/06-VP8. LUA (Latvia University of Agriculture) ZP 07-78 and from 2009-2012. 2009/0212/1DP/1.1.1.2.0/09/APIA/VIAA/060EF7 "Establishment of interdisciplinary scientist group and modelling system for groundwater research".
Scientific field of interests are groundwater quality and quantity, regime of groundwater table, interaction between stream water, drainage and groundwater.

Address: 19 Akademijas street, LV-3001, Jelgava, Latvia

Phone: +371 63029908; +371 29418944

Email: valdis.vircavs@1lu.lv

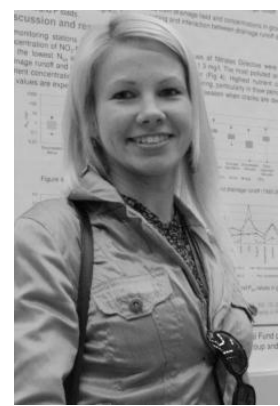

Zane Dimanta, B.sc.ing. Master student, Laboratory assistant, Department of Environmental Engineering and Water Management, Latvia University of Agriculture (LUA). Bachelor of Science (Environmental Management and Environmental Engineering) LUA, 2010. Master thesis "Analysis of Crop Rotation Effects on Nutrient Runoff". Research interests: agricultural impact on groundwater and drainage water quality, water quantity.

Address: 19. Akademijas street, LV-3001, Jelgava, Latvia

Email: zane.dimanta@inbox.lv

Phone: +371 6033065

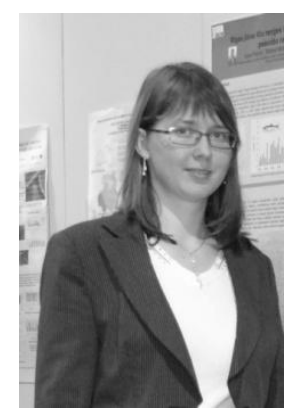

Ilva Vitola, B.sc.ing. Master student, Laboratory assistant, Department of Environmental Engineering and Water Management, Latvia University of Agriculture (LUA). Bachelor of Science (Environmental Management and Environmental Engineering) LUA, 2010. Master thesis "Analysis of possibilities to install environmently friendly river-run hydropower stations in Latvia". Research interests: groundwater seasonal fluctuations.

Address: 19 Akademijas street, LV-3001, Jelgava, Latvia

Email: ilva.anisimova@gmail.com 